\title{
An Investigation of the Factors Influencing Indoor Environmental Quality (IEQ) of Residential Buildings in Gauteng, South Africa
}

\author{
Oluwaseun S. Dosumu ${ }^{1,2^{\star}}$, Clinton O. Aigbavboa \\ 1 Sustainable Human Settlement and Construction Research Centre, Faculty of Engineering and the Built Environment, \\ University of Johannesburg, P.O. Box 524. Auckland Park 2006, South Africa \\ 2 Department of Construction Management, University of Rwanda, BP 3900, Kigali, Rwanda \\ * Corresponding author, e-mail: osdosumu@unilag.edu.ng
}

Received: 02 July 2018, Accepted: 06 February 2019, Published online: 30 April 2019

\begin{abstract}
The study aims to examine the factors affecting the IEQ of buildings with respect to type of building unit, gender, age, ethnicity and directions that the windows of occupants' building units are facing. The study was conducted in Ekurhuleni Metropolitan Municipality (EMM) of South Africa. The descriptive (questionnaire) survey research design (quantitative method) was adopted in the study. The convenience sampling technique was used to collect data for the study. The method of data analysis includes percentages, mean scores, t-test statistic and one-way analysis of variance. The results of the study indicate that the factors investigated in the study were significantly optimum for the IEQ of buildings. However, inferential statistics show that the respondents differed on some factors of IEQ based on age, gender, ethnicity and building unit. Based on the findings, the study concludes that, the factors affecting IEQ of buildings vary according to age, gender and type of building units occupied. Hence, the factors need to be given dedicated consideration whenever design of buildings are to be done. Despite the existence of standards/assessment tools for determining the IEQ of proposed buildings, gender, age and type of units to be provided for occupants should be put into consideration when building projects are to be designed for IEQ.
\end{abstract}

Keywords

building projects, factors affecting IEQ, indoor environmental quality, occupants' satisfaction, South Africa

\section{Introduction}

Housing is one of the most important basic needs of man for both safety and survival (Mui et al., 2005). Also, most persons spend a lot of time in their houses for conducting duties of their daily living. Up to $90 \%$ of people in developed and developing countries spend their time indoor (Frontczak and Wargocki, 2011). This makes indoor environmental conditions of buildings paramount to the welfare, performance and satisfaction of occupants. Buildings are meant to provide healthy and habitable ecosystem for people (Sakhare and Ralegaonkar, 2014). However, in many developing countries (where green building construction are not yet being adopted due to awareness and needed technology to adopt sustainability among others), there are many buildings that are being developed by governments for different categories of citizens for the purpose of habitation and safety (Ibem, 2012). It is however, not clear if those buildings meet up with indoor environmental quality (IEQ) criteria of the occupants, which could have impact on their health and productivity.

There is growing sensitization around the world about the impacts of IEQ on the satisfaction of building occupants in sustainability rated and certified buildings (Huang et al., 2012). While countries such as the United States of America(Leadership in Energy and Environmental Design, LEED), England (Building Research Establishment Environmental Assessment Method, BREEAM) and Hong Kong (Building Environmental Assessment Method, BEAM) among many others have long introduced the concept of IEQ into their building designs, construction and operation, many developing countries including South Africa, are yet to fully embrace this paradigm shift in the design and construction of their building projects (Lee and Guerin, 2010). South Africa has a number of certified green buildings (about 200 as at 2016) but they are 
not only very few; they are mostly commercial (companies) and not residential buildings. IEQ is often not considered as one of the major aspects of construction during design, planning, development and management of building projects especially the non-green construction buildings (Sulaiman et al., 2013). Hence, an imbalance of IEQ is created in buildings. This consequently results in negative impacts on facilities, buildings and occupants; thereby, contributing to poor quality of occupants' health and Sick Building Syndrome (SBS).

This study sensitizes the government of the IEQ of houses that are being provided for the populace. The sensitization will not only enhance provocation towards consideration of IEQ during building designs; it would also lead to improved health, productivity and occupants' overall satisfaction. The study becomes more important as it benchmarks the current method of building design and construction against sustainable design and construction. It will also assist stakeholders to know the sufficiency of the current method of building design in achieving the desired IEQ of buildings. Therefore, the thrust of this research is to investigate occupants on the perceived factors affecting the IEQ of residential building projects.

\section{Literature review}

IEQ is commonly utilized as a part of the connection to the health and well-being of building occupants. It covers indoor air quality, ventilation, thermal conditions, temperature, quality of daylight and access to see (Sulaiman et al., 2013). According to Wong et al. (2008), the components of IEQ can be classified into acoustic comfort; thermal comfort; visual comfort and indoor air quality. IEQ can be evaluated based on many factors which include external conditions, types of buildings, building services and human activities (Franchimon et al., 2009). Interior comfort also consists of studying the interaction between the components of IEQ and their effects on buildings and the people.

IEQ makes up one of the five classes of the Leadership in Energy and Environmental Design (LEED) in the United States (Lee, 2010) and one of the six criteria in the Green Building assessment tool of Malaysia among other raring tools (Raid et al., 2015). Green buildings are designed to reduce the negative impacts of construction activities on the environment as well as increase occupants' health by addressing five factors; (1) sustainable site planning (2) safeguarding water use and water efficiency (3) energy efficiency, renewable energy and lower greenhouse gas emissions (4) conservation, reuse of materials and resources and (5) improved health and IEQ. Researches have been conducted on the IEQ of buildings in Hong Kong's University teaching rooms (Lee et al., 2012), Italian primary schools (Giuli et al, 2012), Greek buildings (Kolokotsaet al., 2009), residential buildings in Slovakia (Földvary, 2016) and Hong Kong offices (Wong et al., 2007) to mention a few. In South Africa however, studies on the IEQ of building projects, as important as they are to the growth and sustainability of the construction industry and the nation at large are very scarce.

An imbalance of IEQ has negative impacts on facilities, structures and occupiers (Aliffadilah, 2008). IEQ is seldom given preference during planning, development and management of building projects. IEQ elements constitute $12 \%$ of sustainability evaluation criteria for housing projects (Raid et al., 2015). In any case, focus towards harmonising IEQ elements is exceptionally significant as it intently relates to thermal conditions which comprises of temperature and dampness that influences indoor air quality (Ibem, 2012). Likewise, the nature of inhabitants' prosperity and satisfaction are more basic since they are impacted by the quality limits in buildings. Gayathri et al. (2016) found that, air quality, warm comfort, lighting and acoustic qualities, outside view, plan of ventilation, cleanliness, support and furniture were the key parts affecting IEQ. They in like manner saw that ability to have singular control on comfort segments in a building impact IEQ. Issues relating to health, comfort and safety are predominantly noticeable in housing where deterioration of existing building stock and the need for renovation is a priority (Awabi, 2007). Across European Union countries, Afacon and Dermikah (2016) noted that, social housing numbers over fifty-five million dwellings; much of which are of poor quality, creates problems of ill-health and insecurity for occupants and maintenance problems for owners.

Ranasinghe et al. (2012) investigated the IEQ of LEED platinum rated green buildings was done by questioning occupants on the thermal comfort of buildings and it was discovered that less number of occupants were satisfied with the thermal comfort of buildings and significant number of them were generally dissatisfied in their workplaces, hence had hampered productivity. Some other external factors around the buildings and workplaces that affected IEQ were discovered while exploring the connection between IEQ and tenants' fulfillment in European office structures (Sakellaris et al., 2016). The investigation discovered that there might be exogenous components like individual attributes of tenants (age, sex, and so on) and 
building qualities (area of building and kind of building) that could be influencing IEQ of buildings. However, since the assertions of these studies were only based on speculations, it is necessary to conduct an empirical study to confirm and justify the effects of personal and building characteristics on IEQ of building projects. It is based on this position, that this study investigates the factors affecting the IEQ of building projects based on gender, age and type of accommodation among others.

\section{Research method}

The study adopted the survey research design method. It was basically a quantitative method of research. The study was conducted on low-cost housing projects in Gauteng province of South Africa. Hence, the population of the study is low-cost residential housing projects in Gauteng, South Africa. The respondents of the study were the occupants that dwelled in low-cost housing projects that were managed by Ekurhuleni Development Company (EDC). Gauteng is the economic hub of South Africa and government invested a lot on housing construction in the province. Ekurhuleni Development Company (EDC) is the major administrator of housing especially low-cost housing projects in Gauteng.

Ekurhuleni Development Company (EDC) is an organization that was established in year 2000 for the advancement and administration of rental apartments for low-income and direct pay families in South Africa. Ekurhuleni Development Company (EDC) was chosen for this study in order to achieve homogeneity of respondents and capture a sizeable number of respondents. Thus, the study was conducted on housing projects that were managed by Ekurhuleni Development Company (EDC).

Because of the staggered periods that occupants of Ekurhuleni Development Company (EDC) stayed at home, the study adopted the convenience sampling techniques by administering the questionnaire of the study on available and willing occupants. There were always representatives of Ekurhuleni Development Company (EDC) on each of the housing estates they manage; hence, the representatives were approached and required to assist with the administration of the questionnaire on occupants as they entered the gates of the estates. Three hundred (300) questionnaires were therefore sent out for the study and only 100 were returned and used for the study, giving a response rate of $33 \%$. The methods of data analysis for the study were percentages, mean item scores, t-test and analysis of variance (ANOVA).

\section{Data analysis}

Table 1 shows the gives the background information of respondents and their buildings. The gender of the respondents indicates that $66 \%$ were females and $34 \%$ were males. This shows that there are more female respondents in the study than males. This may be because women come home earlier than men in most cases and as such are more available. Also, $2 \%$ of respondents were 20-25 years, $20 \%$ were $26-30$ years, $32 \%$ were $31-35$ years, $22 \%$ were $36-40$ years, $16 \%$ were $41-45$ years and $8 \%$ were above 45 years of age. This indicates that majority of the respondents fall within the ages of 26 and 45 years. That is the working-class ages around the world.

Table 1 General information about respondents and their houses

\begin{tabular}{|c|c|}
\hline $\begin{array}{l}\text { Background Information of } \\
\text { respondents }\end{array}$ & Percentage $(\%)$ \\
\hline \multicolumn{2}{|l|}{ Gender } \\
\hline Male & 34 \\
\hline Female & 66 \\
\hline \multicolumn{2}{|l|}{ Age } \\
\hline $20-25$ & 2 \\
\hline $26-30$ & 20 \\
\hline $31-35$ & 32 \\
\hline $36-40$ & 22 \\
\hline $41-45$ & 16 \\
\hline Above 45 & 8 \\
\hline \multicolumn{2}{|l|}{ Ethnicity } \\
\hline Afrikans & 74 \\
\hline Coloured & 26 \\
\hline \multicolumn{2}{|c|}{ Number of years in building unit } \\
\hline Less than 1 year & 16 \\
\hline $1-5$ & 44 \\
\hline $6-10$ & 40 \\
\hline \multicolumn{2}{|l|}{ Floor level of respondent } \\
\hline First & 50 \\
\hline Second & 22 \\
\hline Third & 18 \\
\hline Fourth & 10 \\
\hline \multicolumn{2}{|c|}{ Direction of occupants' buildings } \\
\hline North & 20 \\
\hline East & 26 \\
\hline West & 8 \\
\hline Core & 18 \\
\hline Do not know & 28 \\
\hline \multicolumn{2}{|l|}{ Type of unit occupied } \\
\hline 2-bedroom unit & 74 \\
\hline 1-bedroom unit & 26 \\
\hline
\end{tabular}


Moreover, $74 \%$ of the respondents were Afrikans while $22 \%$ were coloured. There were no whites represented in this study and that may be due to some reasons that were not investigated in this study. But, it could mean that whites do not stay in the buildings investigated in the study. Those that had spent less than 1year in their apartments were $16 \%, 1-5$ years were $44 \%$ and 6-10 years were $40 \%$. Also, $50 \%$ lived on the first floor, $22 \%$ lived on the second floor, $18 \%$ lived on the third floor and $10 \%$ lived on the fourth floor. Furthermore, $20 \%$ had their windows facing the North, $26 \%$ had their windows facing the east, $8 \%$ had their windows facing west, $18 \%$ had their window facing south and $28 \%$ did not know where their windows faced. Lastly, $74 \%$ of the respondents lived in 2-bedroom units while $26 \%$ lived in 1-bedroom unit. This indicates that the respondents for the study were adequately spread across the floor they lived, across the orientation of their buildings and across the sizes of apartments. Also, since the low-income buildings were investigated, they were mostly small apartments of 1 and 2-bedroom units.

Table 2 indicates the occupants' control over facilities in their homes. The study believes that the level of occupants' control over certain facilities could influence occupants' satisfaction with IEQ of their buildings. The ability to adjust window blinds (3.96) was rated highest in this category, followed by use of operable windows (3.55), access to doors to exterior space (3.55) and doors to interior space (3.31). The remaining facilities outside the ones mentioned were mostly electrical units that have been pre-installed, thereby do not give occupants the opportunity to adjust or operate them. This may provide justification for the low rating of those facilities in the buildings. One of the staff of Ekurhuleni Development Company (EDC), during an

Table 2 Occupant's control over facilities in their unit ( $5=$ Very High; 4 = High; 3 = Average; 2 =Low; 1 = Very Low, $\mathrm{R}=$ Rank)

\begin{tabular}{lcc}
\hline Adjustable Facilities & Mean & Rank \\
\hline Window blinds /curtains & 3.96 & 1 \\
Operable window & 3.55 & 2 \\
Door to exterior space & 3.55 & 2 \\
Door to interior space & 3.31 & 4 \\
Portable heater & 2.47 & 5 \\
Thermostat/ Sensor & 2.16 & 6 \\
Portable fan & 1.96 & 7 \\
Room air-conditioning unit & 1.69 & 8 \\
Adjustable floor air vent (diffuser) & 1.53 & 9 \\
Ceiling fan & 1.45 & 10 \\
None of the above & 1.20 & 11 \\
\hline
\end{tabular}

informal discussion noted that some of the facilities listed in the questionnaire were not existent in the buildings. The non-existence was mentioned to be due to factors which range from weather in South Africa to the standard/type of occupants the houses were being prepared for.

Table 3 shows the perception of occupants on the factors that affected the IEQ of their buildings based on the types of units they occupied. On the overall, the most favoured factors affecting IEQ was, time spent inside the units (3.74), followed by size of windows (3.70), colour and smoothness of flooring, etc. (3.66), visual comfort of lighting (3.62), amount of light in unit (3.58), general cleanliness of the buildings (3.50) and the directions the buildings were facing among others (3.48). The ratings appeared less satisfactory (Less than 4.0) for residential buildings where people expectedly spent majority of their time, hence determining how healthy and productive they could be in their daily activities. This shows that, measures should be put in place to ensure that all these factors were given more consideration during the design of buildings.

In addition to the descriptive statistics, t-test was run to determine, if there was difference in the factors affecting the IEQ of occupants living in 2-bedroom and 1-bedroom units. The result of the test shows that among the 17 factors investigated in this study, there was significant difference $(\mathrm{P}<0.005)$ in the factors affecting IEQ on six $(6)$ variables which were visual comfort of lighting, directions buildings were facing, air quality in the units, general maintenance, level of privacy and spaces available in buildings.

In practical terms, it means that the quality of visual comfort of lighting, directions buildings were facing, air quality in the units, general maintenance, level of privacy and spaces available in buildings were significantly different. There is tendency for the designers of the buildings to allocate more comfort, lighting, air quality and privacy to occupants of 2-bedroom units than those of 1-bedroom units. Therefore, even though both sets of respondents appreciated the factors investigated as affecting IEQ by rating them fairly high, their level of admission varies. This is evident in the comparison of the mean scores for both set of respondents on the variables of the study. It could be observed that the values for occupants of 2-bedroom units were quite higher than those of 1-bedroom units.

Table 4 shows the rating of the factors affecting the IEQ of buildings based on the gender of occupants. Independent sample t-test statistics was also run on the factors to determine if there was difference in their ranking based on gender. Result indicates that there were significant differences 
Table 3 Factors influencing the IEQ of residential buildings based on types of unit 5-very significant (VS); 4-Significant (S); 3-Average/Do not know (AV/DK); 2-Slightly Significant (SS); 1-Not Significant (NS); P $<0.05=$ significant $=$ reject $\mathbf{H o} ; \mathbf{R}=\mathbf{R a n k}$

\begin{tabular}{|c|c|c|c|c|c|c|c|c|}
\hline & 2 bedroom & & 1 bedroom & & Overall & & & \\
\hline Significant Factors & Mean & $\mathbf{R}$ & Mean & $\mathbf{R}$ & MIS & $\mathbf{R}$ & p-value & Decision \\
\hline Time spent inside the unit & 3.81 & 2 & 3.54 & 3 & 3.74 & 1 & 0.302 & Accept Ho \\
\hline Size of the windows & 3.95 & 1 & 3.00 & 12 & 3.70 & 2 & 0.225 & Accept Ho \\
\hline Colour and smoothness of flooring and furniture & 3.57 & 8 & 3.92 & 1 & 3.66 & 3 & 0.240 & Accept Ho \\
\hline Visual comfort of the lighting & 3.70 & 3 & 3.38 & 6 & 3.62 & 4 & 0.000 & Reject Ho \\
\hline Amount of light in the unit & 3.70 & 3 & 3.23 & 9 & 3.58 & 5 & 0.230 & Accept Ho \\
\hline General cleanliness of the building & 3.59 & 6 & 3.23 & 9 & 3.50 & 6 & 0.409 & Accept Ho \\
\hline Direction the building is facing & 3.65 & 5 & 3.00 & 12 & 3.48 & 7 & 0.029 & Reject Ho \\
\hline Types of building materials used & 3.59 & 6 & 2.85 & 14 & 3.40 & 8 & 0.290 & Accept Ho \\
\hline Comfort of furnishings & 3.35 & 9 & 3.46 & 4 & 3.38 & 9 & 0.541 & Accept Ho \\
\hline Air quality in the unit & 3.35 & 9 & 3.31 & 8 & 3.34 & 10 & 0.013 & Reject Ho \\
\hline Type of activities conducted whilst in the unit & 3.14 & 14 & 3.62 & 2 & 3.26 & 11 & 0.563 & Accept Ho \\
\hline General maintenance of the building & 3.14 & 14 & 3.23 & 9 & 3.16 & 14 & 0.007 & Reject Ho \\
\hline Temperature in the unit & 3.19 & 12 & 2.77 & 16 & 3.08 & 15 & 0.265 & Accept Ho \\
\hline Level of privacy & 3.08 & 16 & 2.85 & 14 & 3.02 & 16 & 0.061 & Reject Ho \\
\hline $\begin{array}{l}\text { Available area for individual daily storage, } \\
\text { recreation, etc. }\end{array}$ & 3.35 & 9 & 2.77 & 16 & 3.20 & 13 & 0.013 & Reject Ho \\
\hline $\begin{array}{l}\text { Sound insulation between units (ability to talk } \\
\text { without being overheard) }\end{array}$ & 3.19 & 12 & 3.46 & 4 & 3.26 & 11 & 0.329 & Accept Ho \\
\hline
\end{tabular}

$(\mathrm{P}<0.005)$ in eight $(8)$ factors out of the 17 that were investigated based on the gender of occupants. The factors affected were visual comfort of lighting, amount of time spent in the units, sizes of window, general maintenance of buildings, colour and smoothness of flooring and temperatures in the units among others. This shows that gender had influence on the lighting comfort, amount of time spent in units and temperatures in the building units among others. Therefore, gender of proposed occupants need to be significantly factored into building designs before construction commences.

Table 5 indicates the differences in the choices of respondents on the factors affecting the IEQ of buildings based on age, ethnicity and directions windows were facing.

The age and directions faced by windows were tested with one-way analysis of variance (ANOVA) because there are more than two categories of respondents involved; ethnicity was tested with independent samples t-test. Result shows that based on age, occupants differed $(P<0.005)$ in their choices of factors affecting the IEQ on 12 out of the 17 factors that were investigated in this study. Based on ethnicity, occupants differed on eight (8) out of the 17 factors investigated in the study and based on the directions faced by windows, occupants differed on 15 out of the 17 factors investigated in the study. The implication of this result is that age, ethnicity and directions faced by windows affects the satisfaction of occupants with the IEQ of buildings they occupy.

\section{Summary and discussion of findings}

Table 6 summarizes the differences in the factors affecting the IEQ of buildings based on the individual characteristics of respondents and their building units. Evident in the summary (Table 6) was the significant difference in the visual comfort of lighting for occupants based on age, type of unit, ethnicity, gender and directions faced by windows of occupants' buildings. Other factors that had significant differences based on personal characteristics were colour and smoothness of flooring, air quality, sound privacy between units and general maintenance of buildings.

The result of this study generally supports the assertions of Ranasingheet al. (2012) and Sakellaris et al. (2016) that there are other personal attributes (like age and gender) and building characteristics (location and type of buildings) that determine occupants' satisfaction with IEQ. The authors investigated sustainability rated and certified buildings and found that in spite of the certifications, occupants still get dissatisfied with some of the IEQ elements. This study was however conducted on uncertified buildings, and occupants' response affirmed that personal and 
Table 4 Factors affecting IEQ of residential buildings based on gender

5-very significant (VS); 4-Significant (S); 3-Average/Don't know (AV/DK); 2-Slightly Significant (SS); 1 - Not Significant (NS); P < 0.05 = significant $=$ reject $\mathrm{Ho}$

\begin{tabular}{|c|c|c|c|c|c|c|}
\hline Significant Factors & Female & Rank & Male & Rank & p-value & Decision \\
\hline Visual comfort of the lighting (e.g. glare, reflections, contrast) & 3.45 & 6 & 3.94 & 1 & 0.009 & Reject Ho \\
\hline Amount of time spent inside the unit & 3.73 & 2 & 3.76 & 2 & 0.001 & Reject Ho \\
\hline Size of the windows & 3.70 & 3 & 3.71 & 3 & 0.014 & Reject Ho \\
\hline Direction that the building is facing & 3.36 & 8 & 3.71 & 3 & 0.059 & Accept Ho \\
\hline Type of activities conducted whilst in the unit & 3.03 & 15 & 3.71 & 3 & 0.963 & Accept Ho \\
\hline General maintenance of the building & 2.88 & 17 & 3.71 & 3 & 0.002 & Reject Ho \\
\hline Air quality in the unit (i.e. stuffy/stale air, cleanliness, odours) & 3.24 & 11 & 3.53 & 7 & 0.066 & Accept Ho \\
\hline General cleanliness of the building & 3.52 & 5 & 3.47 & 8 & 0.511 & Accept Ho \\
\hline Amount of light in the unit & 3.64 & 4 & 3.47 & 8 & 0.419 & Accept Ho \\
\hline Types of building materials used & 3.36 & 8 & 3.47 & 8 & 0.374 & Accept Ho \\
\hline $\begin{array}{l}\text { Amount of space available for individual daily activities } \\
\text { (storage, recreation, etc.) }\end{array}$ & 3.06 & 14 & 3.47 & 8 & 0.090 & Accept Ho \\
\hline Colour and smoothness of flooring and furniture & 3.82 & 1 & 3.35 & 12 & 0.009 & Reject Ho \\
\hline Temperature in the unit & 2.97 & 16 & 3.29 & 13 & 0.014 & Reject Ho \\
\hline Comfort of furnishings & 3.45 & 6 & 3.24 & 14 & 0.002 & Reject Ho \\
\hline $\begin{array}{l}\text { Sound privacy between units (ability to have conversations } \\
\text { without neighbours' overhearing) }\end{array}$ & 3.27 & 10 & 3.24 & 14 & 0.005 & Reject Ho \\
\hline Level of privacy & 3.15 & 12 & 2.76 & 16 & 0.538 & Accept Ho \\
\hline Ability to adjust or move furniture to meet occupants' needs & 3.12 & 13 & 2.53 & 17 & 0.153 & Accept Ho \\
\hline
\end{tabular}

Table 5 Difference in the factors affecting IEQ based on age, ethnicity and direction of window $\mathrm{P}<0.05=$ significant $=$ reject $\mathrm{Ho}$

\begin{tabular}{|c|c|c|c|c|c|c|}
\hline Significant Factors & $\begin{array}{l}\text { p-value } \\
\text { (Age) }\end{array}$ & Decision & $\begin{array}{l}\text { p-value } \\
\text { (Ethnicity) }\end{array}$ & Decision & $\begin{array}{c}\text { p-value } \\
\text { (Direction } \\
\text { of window) }\end{array}$ & Decision \\
\hline $\begin{array}{l}\text { Amount of space available for individual daily } \\
\text { activities (storage, recreation, etc,) }\end{array}$ & 0.122 & Accept Ho & 0.000 & Reject Ho & 0.014 & Reject Ho \\
\hline Level of privacy & 0.000 & Reject Ho & 0.086 & Accept Ho & 0.000 & Reject Ho \\
\hline Comfort of furnishings & 0.000 & Reject Ho & 0.104 & Accept Ho & 0.002 & Reject Ho \\
\hline $\begin{array}{l}\text { Ability to adjust or move furniture to meet } \\
\text { occupant's needs }\end{array}$ & 0.000 & Reject Ho & 0.481 & Accept Ho & 0.046 & Reject Ho \\
\hline Colour and smoothness of flooring and furniture & 0.001 & Reject Ho & 0.000 & Reject Ho & 0.048 & Reject Ho \\
\hline Temperature in the unit & 0.210 & Accept Ho & 0.190 & Accept Ho & 0.000 & Reject Ho \\
\hline Air quality in the unit & 0.010 & Reject Ho & 0.023 & Reject Ho & 0.000 & Reject Ho \\
\hline Amount of light in the unit & 0.304 & Accept Ho & 0.860 & Accept Ho & 0.416 & Accept Ho \\
\hline Direction that the building is facing & 0.023 & Reject Ho & 0.162 & Accept Ho & 0.002 & Reject Ho \\
\hline Size of the windows & 0.755 & Accept Ho & 0.012 & Reject Ho & 0.003 & Reject Ho \\
\hline Daylight comfort & 0.017 & Reject Ho & 0.019 & Reject Ho & 0.016 & Reject Ho \\
\hline $\begin{array}{l}\text { Sound privacy between units (ability to have } \\
\text { conversations without neighbours overhearing) }\end{array}$ & 0.011 & Reject Ho & 0.029 & Reject Ho & 0.000 & Reject Ho \\
\hline General cleanliness of the building & 0.012 & Reject Ho & 0.005 & Reject Ho & 0.000 & Reject Ho \\
\hline General maintenance of the building & 0.000 & Reject Ho & 0.639 & Accept Ho & 0.000 & Reject Ho \\
\hline Types of building materials used & 0.002 & Reject Ho & 0.555 & Accept Ho & 0.000 & Reject Ho \\
\hline Amount of time spent inside the unit & 0.347 & Accept Ho & 0.117 & Accept Ho & 0.632 & Accept Ho \\
\hline Type of activities conducted whilst in the unit & 0.000 & Reject Ho & 0.040 & Reject Ho & 0.000 & Reject Ho \\
\hline
\end{tabular}


Table 6 Summary of difference in the factors affecting IEQ based on individual characteristics $\mathrm{X}=$ no significant difference, $\mathrm{v}=$ significant difference

\begin{tabular}{|c|c|c|c|c|c|}
\hline Significant Factors & Age & Type of unit & Ethnicity & Gender & Direction of window) \\
\hline Available area for daily storage, recreation, etc. & $\mathrm{x}$ & $\vee$ & $\vee$ & $\mathrm{x}$ & $\vee$ \\
\hline Level of privacy & $\vee$ & $\vee$ & $\mathrm{x}$ & $\mathrm{x}$ & $\vee$ \\
\hline Comfort of furnishings & $\vee$ & $\mathrm{X}$ & $\mathrm{x}$ & $\vee$ & $\vee$ \\
\hline Ability to move furniture to suit occupant's needs & $\vee$ & $\mathrm{X}$ & $\mathrm{x}$ & $\mathrm{x}$ & $\vee$ \\
\hline $\begin{array}{l}\text { Colours and smoothnesss of floor, furniture and } \\
\text { finishes }\end{array}$ & $\vee$ & $\mathrm{X}$ & $\vee$ & $\vee$ & $\vee$ \\
\hline Temperature in the unit & $\mathrm{x}$ & $\mathrm{X}$ & $\mathrm{x}$ & $\vee$ & $\vee$ \\
\hline Quality of air in the unit & $\vee$ & $\vee$ & $\vee$ & $\mathrm{x}$ & $\vee$ \\
\hline Direction that the building is facing & $\vee$ & $\vee$ & $\mathrm{x}$ & $\mathrm{x}$ & $\vee$ \\
\hline Size of the windows & $\mathrm{x}$ & $\mathrm{X}$ & $\vee$ & $\vee$ & $\vee$ \\
\hline Daylight comfort & $\vee$ & $\vee$ & $\vee$ & $\vee$ & $\vee$ \\
\hline $\begin{array}{l}\text { Sound insulation within units (ability to have talk } \\
\text { without being overheard) }\end{array}$ & $\vee$ & $\mathrm{X}$ & $\vee$ & $\vee$ & $\vee$ \\
\hline Neatness of building & $\vee$ & $\mathrm{X}$ & $\vee$ & $\mathrm{x}$ & $\vee$ \\
\hline Maintenance of building & $\vee$ & $\vee$ & $\mathrm{x}$ & $\vee$ & $\vee$ \\
\hline Types of building materials used & $\vee$ & $\mathrm{X}$ & $\mathrm{x}$ & $\mathrm{x}$ & $\vee$ \\
\hline Time spent inside the unit & $\mathrm{x}$ & $\mathrm{X}$ & $\mathrm{x}$ & $\vee$ & $\mathrm{X}$ \\
\hline Type of activities carried out in the unit & $\vee$ & $\mathrm{X}$ & $\vee$ & $x$ & 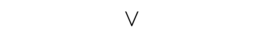 \\
\hline
\end{tabular}

buildings' characteristics would affect their comfort with the IEQ of the buildings. This shows that certifying establishments like LEED, BEAM, BREEAM, Green Star SA and the likes, need to also find a way to incorporate the influence of personal attributes (age, gender, ethnicity, etc.) and building characteristics like type of buildings into the designs of IEQ for building projects.

\section{Conclusion}

Based on the results of this study, it was concluded that occupants had control over facilities that were not pre-installed and non-electrical in their units. The study further concludes that all the factors investigated in this study significantly influenced the indoor environmental qualities of occupants' buildings or units. However, based on certain personal characteristics (age, gender,

\section{References}

Afacan, Y., Demirkan, H. (2016) "The influence of sustainable design features on indoor environmental quality satisfaction in Turkish dwellings", Architectural Science Review, 59(3), pp. 229-238. https://doi.org/10.1080/00038628.2015.1056768

Aliffadilah, J. (2008) "The Indoor Environmental Impact on ResidentialIndustrial Neighborhood in Paka Industrial Estate, Terengganu", BSc Thesis, Universiti Teknologi, Malaysia.

Awabi, B. H. (2007) "Ventilation Systems: Design and Performance", Psychology press, New York, USA. and ethnicity) and that of the building units occupied, there were significant differences in some of the factors of IEQ investigated in this study. Atop of the factors that were significantly different based on the investigated personal characteristics and attributes were visual comfort of lighting in building units, air quality, sound privacy between different building units, colour and smoothness of floor and general maintenance of buildings. Based on these findings, the study recommends that, even though there are standard values and rating systems for the IEQ of buildings based on the criteria of certifying establishments (Green Star SA), additional considerations should be given to visual comfort, air quality, sound privacy, type of floor finish and general maintenance of buildings based on gender, age, ethnicity and type of unit to be allocated to occupants.

Franchimon, F., Dijken, F. V., Pernot, C. E., Bronswijk, J. E. (2009) "Airexchange rate under debate. Healthy buildings", Syracuse, NY, USA.

Frontczak, M., Wargocki, P. (2011) "Literature survey on how different factors influence human comfort in indoor environments", Building and Environment, 46(4), pp. 922-937. https://doi.org/10.1016/j.buildenv.2010.10.021

Gayathri, L., Perera, B. A., Sumanarathna, D. M. (2016) "Factors affecting the indoor environmental quality in Sri Lanka: Green vs. Conventional hotel buildings", In: The $5^{\text {th }}$ World Construction Symposium 2016: Greening Environment, Economic Innovations \& Entrepreneurship, Colombo, Sri Lanka, pp. 210-220. 
Giuli, V. D., Da Pos, O., De Carli, M. (2012) "Indoor environmental quality and pupil perception in Italian primary schools", Building and Environment, 56, pp. 335-345.

https://doi.org/10.1016/j.buildenv.2012.03.024

Huang, L., Zhu, Y., Ouyang, Q., Cao, B. (2012) "A study on the effects of thermal, luminous, and acoustic environments on indoor environmental comfort in offices", Building and Environment, 49, pp. 304-309.

https://doi.org/10.1016/j.buildenv.2011.07.022

Ibem, O. E. (2012) "Residents' perception of the quality of public housing in urban areas in Ogun State, Nigeria", International Journal of Quality and Reliability Management, 29(9), pp. 1000-1018. https://doi.org/10.1108/02656711211272917

Kolokotsa, D., Pouliezos, A., Stavrakakis, G., Lazos, C. (2009) "Predictive control techniques for energy and indoor environmental quality management in buildings", Building and Environment, 44(9), pp. 1850-1863.

https://doi.org/10.1016/j.buildenv.2008.12.007

Lee, Y. S. (2010) "Office layout affecting privacy, interaction, and acoustic quality in LEED-certified buildings", Building and Environment, 45(7), pp. 1594-1600. https://doi.org/10.1016/j.buildenv.2010.01.007

Lee, Y. S., Guerin, D. A. (2010) "Indoor environmental quality differences between office types in LEED-certified buildings in the US", Building and Environment, 45(5), pp. 1104-1112 https://doi.org/10.1016/j.buildenv.2009.10.019

Lee, M. C.., Mui, K. W., Wong, L. T., Chan, W. Y., Lee, E. W., Cheung, C. T. (2012) "Student learning performance and indoor environmental quality (IEQ) in air-conditioned university teaching rooms", Building and Environment, 49, pp 238-244. http://doi:10.1016/j.buildenv.2011.10.001

Mui, K. W., Chan, W. T. (2005) "A new indoor environmental equation for air-conditioned buildings", Architectural Science Review, 48(1), pp. 41-46.

http://doi.org//10.3763//asre.2005.4806

Raid, M. M., Kasim, A. C., Hussin, K. (2015) "Impact of indoor environmental quality and Innovation (IN) Features on Residential Property Price in Malaysia: A Review", In: Proceedings of $22^{\text {nd }}$ European Real Estate Society Conference, Istanbul, Turkey, pp. $63-73$.
Ranasinghe, A. W., Perera, A. A. Halwatura, R. U. (2012) "Occupant Satisfaction on Indoor Comfort in a Green Building", In: Proceedings of the International Symposium on Advances in Civil and Environmental Engineering Practices for Sustainable Development (ACEPS), Sri Lanka, pp. 272-279.

Sakellaris, I. A., Saraga, D. E., Mandin, C., Roda, C., Fossati, S., Kluizenaar, Y., Carrer, P. Dimitroulopoulou, S., Mihucz, V. G., Szigeti, T., Hänninen, O., Fernandes, E. O., Bartzis, J. G., Bluyssen, P. M. (2016) "Perceived Indoor Environment and Occupants' Comfort in European "Modern" Office Buildings: The OFFICAIR Study", International Journal of Environmental Research and Public Health, 13(5), pp. 1-15. https://doi.org/10.3390/ijerph13050444

Sakhare, V. V., Ralegaonkar, R. V. (2014) "Indoor environmental quality: review of parameters and assessment models", Architectural Science Review, 57(2), pp. 147-154. https://doi.org/10.1080/00038628.2013.862609

Samari, M., Ghodrati, N., Esmaeilifar, R., Olfat, P., Shafiei, M. W. (2013) "The Investigation of the Barriers in Developing Green Building in Malaysia", Modern Applied Science, 7(2), pp. 63-73. https://doi.org/10.5539/mas.v7n2p1

Sulaiman, M. A., Yusoff, W. W., Kamarudin, W. W. (2013) "Evaluation of indoor environmental quality on dense Academic Building: Case Studies of Universiti Tun Hussein Onn Malaysia", International Journal of Scientific and Research Publications, 3(1) pp. 348-352. [online] Available at: http://www.ijsrp.org/research-paper-1301/ ijsrp-p1363.pdf [Accessed: 12 April 2017]

Foldvary, V. (2016) "Assessment of indoor environmental quality in residential buildings before and after renovation", PhD Thesis, Slovak University of Technology in Bratislava.

Wong, L. T., Mui, K. W., Hui, P. S. (2008) "A multivariate-logistic model for acceptance of indoor environmental quality in offices", Building and Environment, 43(1), pp. 1-6. https://doi.org/10.1016/j.buildenv.2007.01.001 